\title{
PENGARUH BUDAYA ORGANISASI, LINGKUNGAN KERJA, BEBAN KERJA DAN DISIPLIN TERHADAP KINERJA GURU SMA MUHAMMADIYAH 1 GRESIK
}

\author{
Erni Purwanti \\ Progam Studi Manajemen \\ Fakultas Ekonomi- Universitas Muhammadiyah Gresik \\ Jl. Sumatra No. 101 GKB Gresik 61121 Jawa Timur Indonesia
}

\begin{abstract}
This study aims to examine the influence of Organizational Culture, Work Environment, Workload and Discipline on Teacher Performance of Muhammadiyah Gresik High School. Then a literature review and hypotheses are carried out, as well as data obtained from questionnaires to 55 Muhammadiyah 1 Gresik High School Teachers using Total techniques. Sampling. Testing is done using multiple linear regression analysis. The results of the analysis show that organizational culture has a significant effect on teacher performance variables, the work environment has no effect on teacher performance variables, workload has a significant effect on teacher performance variables, discipline has a significant effect on teacher performance variables.
\end{abstract}

\section{PENDAHULUAN}

Pendidikan merupakan faktor yang paling penting dalam kehidupan manusia. Perkembangan pendidikan manusia akan berpengaruh terhadap dinamika sosial-budaya masyarakatnya. Sejalan dengan itu, pendidikan akan terus mengalami perkembangan sesuai dengan perkembangan kebudayaan. Dengan demikian, jelaslah bahwa pendidikan adalah sesuatu yang sangat penting dan mutlak bagi umat manusia. Oleh karena itu pendidikan tidak hanya sekedar transfer ilmu pengetahuan (transfer of knowledge). Pendidikan bertujuan untuk menciptakan pribadi yang memiliki sikap dan kepribadian yang positif. Guru harus senantiasa mengembangkan diri dan mendayagunakan sumber daya yang dimiliki agar dapat memberikan pelayanan yang terbaik kepada peserta didik. Guru yang mempunyai keinginan untuk meningkatkan kinerja perlu memiliki karakteristik, yang antara lain: berorientasi pada prestasi, memiliki percaya diri, berpengendalian diri, dan memiliki kompetensi.

Kinerja guru adalah kemampuan seorang guru dalam melaksanakan proses pembelajaran di kelas sesuai dengan tujuan yang telah ditetapkan Sumarno (2009: 20). Dimana kemampuan tersebut telah mencakup beberapa aspek, diantaranya: perencanaan program belajar mengajar, pelaksanaan proses belajar mengajar, penciptaan dan pemeliharaan kelas yang optimal, pengendalian kondisi
Keywords: Organizational Culture, Work Environment, Workload and Discipline belajar yang optimal, serta penilaian hasil belajar. Kinerja tentu menjadi faktor yang sangat penting dalam menentukan kualitas kerja seseorang termasuk seorang guru.

SMA Muhammadiyah 1 Gresik adalah salah satu sekolah favorit di Kabupaten Gresik. Didirikan pada 1 September 1965, SMA Muhammadiyah 1 Gresik didirikan oleh Pimpinan Muhammadiyah Cabang Gresik memulai proses belajar mengajar pada 1 September 1966. Pada saat itu masih belum memiliki gedung sekolah sendiri, namun meminjam gedung sekolah lain. Menyadari pentingnya fasilitas dalam mendukung pembelajaran, sedikit demi sedikit pengembangan telah dilakukan. Kerja keras, kerja cerdas, dan kerja ikhlas dari semua warga sekolah membuahkan hasil peningkatan prestasi. Pada tanggal 22 Desember 1976 Pimpinan Pusat Muhammadiyah mengesahkan pendirian SMA Muhammadiyah 1 Gresik. Kemudian mendapatkan piagam pendirian no.1337/II-01/T,.65/1978 tertanggal 5 Dzulhijjah $1938 \mathrm{H}$ bertepatan dengan tanggal 6 Mei 1978. SMA Muhammadiyah 1 Gresik adalah salah satu sekolah favorit di Kabupaten Gresik ini mempunyai jumlah siswa tahun ajaran 2016 - 2017 sebesar 748 siswa dan memiliki tenaga pengajar atau guru sebanyak 55 orang guru.

Kinerja guru adalah kemampuan seorang guru dalam melaksanakan proses pembelajaran di kelas sesuai dengan tujuan 
yang telah ditetapkan Sumarno (2012:20). Dimana kemampuan tersebut telah mencakup beberapa aspek, diantaranya: perencanaan program belajar mengajar, pelaksanaan proses belajar mengajar, penciptaan dan pemeliharaan kelas yang optimal, pengendalian kondisi belajar yang optimal, serta penilaian hasil belajar. Kinerja tentu menjadi faktor yang sangat penting dalam menentukan kualitas kerja seseorang termasuk seorang guru.. Menurut Siagian (2002: 27) budaya organisasi adalah kesepakatan bersama tentang nilai yang dianut bersama dalam kehidupan organisasi dan mengikat semua orang dalam organisasi yang bersangkutan. Budaya organisasi adalah persepsi yang sama dikalangan seluruh anggota organisasi tentang makna hakiki kehidupan bersama (Siagian, 2002: 187). Robbins (2002:279) mendefinisikan budaya organisasi (organization culture) sebagai suatu sistem makna bersama yang dianut oleh anggotaanggota yang membedakan organisasi dengan organisasi lain. Lebih lanjut, Robbins (2002:279) menyatakan bahwa sistem pemaknaan bersama dibentuk oleh warganya yang sekaligus menjadi pembeda dengan organisasi lain. Indikator budaya organisasi menurut Victor Tan dalam Wibowo (2006:349) adalah sebagai berikut:

1. Inisiatif perseorangan

2. Toleransi terhadap resiko

3. Pengawasan

4. Dukungan manajemen

5. Pola komunikasi

Lingkungan kerja menurut Nitisemito, oleh penelitian Nasution dan Rodhiah dalam (Jurnal Manajemen, 2008:58) adalah segala sesuatu yang ada disekitar pekerjadan yang dapat mempengaruhi dirinya dalam menjalankan tugas-tugas yang dibebankan. Lingkungan kerja meliputi pewarnaan, kebersihan, pertukaran udara, penerangan, musik, keamanan dan kebisingan (Nitisemito, 1992: 184). Adapun indikator lingkungan kerja adalah:

1. Penerangan

2. Kebisingan

3. Ruang gerak yang diperlukan

4. Hubungan karyawan

Beban Kerja

Beban kerja adalah frekuensi kegiatan rata-rata dari masing-masing pekerjaan dalam jangka waktu tertentu. Beban kerja meliputi beban kerja fisik maupun mental. Akibat beban kerja yang terlalu berat atau kemampuan fisik yang terlalu lemah dapat mengakibatkan seorang pegawai menderita gangguan atau penyakit akibat kerja (Irwandy, 2007).

Adapun indikator beban kerja adalah:

1. Target Yang Harus Dicapai

2. Kondisi Pekerjaan

3. Standar Pekerjaan

\section{Disiplin}

Disiplin berasal dari akar kata disciple yang berarti belajar. Disiplin merupakan arahan untuk melatih dan membentuk seseorang melakukan sesuatu menjadi lebih baik. Disiplin adalah suatu proses yang dapat menumbuhkan perasaan seseorang untuk mempertahankan dan meningkatkan tujuan organisasi secara obyektif, melalui kepatuhannya menjalankan peraturan oraganisasi.

Definisi menurut para ahli peneliti hasilkan dari pencarian di buku-buku yang telah ada : Menurut Simamora (2007:476) Disiplin adalah prosedur yang mengoreksi atau menghukum bawahan karena melanggar peraturan atau prosedur. Menurut Siagian (2009: 305) Disiplin merupakan tindakan manajemen untuk mendorong para anggota organisasi memenuhi tuntutan berbagai ketentuan tersebut. Dengan adanya definisi diatas dapat disimpulkan, disiplin pada hakekatnya merupakan pembatasan kebebasan dari pegawai.

Kinerja menurut Rivai (2009; 14) menyatakan bahwa kinerja adalah hasil atau tingkat keberhasilan seseorang secara keseluruhan selama periode tertentu di dalam melaksanakan tugas dibandingkan dengan berbagai kemungkinan, seperti standar hasil kerja, target atau sasaran atau kriteria yang telah ditentukan terlebih dahulu dan telah disepakati bersama.

Kinerja karyawan menurut Chishty (2010:12) ia berpendapat untuk mengukur apakah karyawan berkinerja baik pada pekerjaan mereka, pengukuran karyawan dapat bervariasi berdasarkan sifat pekerjaan, jenis organisasi dan sector organisasi. Secara umum indikator kinerja diukur dari:
1. Ketepatan Waktu
2. Deskripsi Pekerjaan
3. Kuantitas
4. Kualitas 


\section{Kerangka Berpikir}

Kerangka pemikiran merupakan penjelasan sementara terhadap gejala - gejala yang menjadi objek permasalahan, dengan gaya kepempinan (X1) disiplin (X2) dan motivasi (X3) merupakan variabel bebas (independent variabel), sedangakan kinerja karyawan (Y) merupakan variabel terikat (dependent variabel). pada penelitian ini akan menguji atau mencari adanya pengaruh signifikan antara variabel bebas dengan variabel terikat.

Gambar 1. Kerangka berfikir

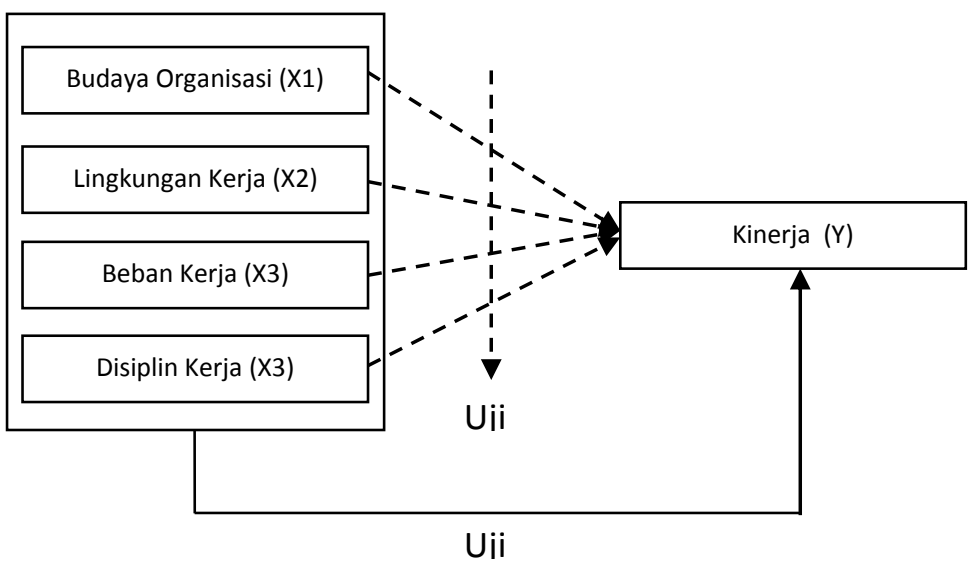

METODE PENELITIAN

Pendekatan Penelitian

Penelitian yang akan dilakukan merupakan penelitian kuantitatif yaitu penelitian ilmiah yang sistematis terhadap bagian-bagian dan fenomena serta hubungan-hubungannya. Menurut Sugiyono (2008:78) pengukuran kuantitatif adalah definisi, pengukuran data kuantitatif dan statistik objektif melalui perhitungan ilmiah berasal dari sampel orangorang atau penduduk yang diminta menjawab atas sejumlah pertanyaan tentang survei untuk menentukan frekuensi dan persentase tanggapan mereka.

\section{Lokasi Penelitian}

Penelitian ini dilaksanakan di SMA Muhammadiyah 1 Gresik, yang berada diJl. KH. Kholil No.90, Pekelingan, Kec. Gresik, Kabupaten Gresik, Jawa Timur 61115, Indonesia.

\section{Populasi dan Sampel}

Populasi dalam suatu penelitian merupakan kumpulan individu atau obyek yang merupakan sifat-sifat umum. Arikunto (2010;173) menjelaskan bahwa "populasi adalah keseluruhan subjek penelitian." Maka dari penjelasan para ahli tersebut, penulis menetapkan populasi dalam penelitian ini adalah guru di SMA Muhammadiyah 1 Gresik yang berjumlah 55 guru.

Menurut Sugiyono (2008:116) "sampel adalah sebagian dari jumlah dan karakteristik yang dimiliki oleh populasi tersebut". Metode penarikan sampel dalam penelitian ini adalah penelitian yang menggunakan seluruh anggota polpulasinya disebut sampel total (total sampling) atau sensus. Penggunaan metode ini berlaku jika anggota populasi relatif kecil (mudah dijangkau). Dalam penelitian ini, karena jumlah populasi relatif kecil dan relatif mudah dijangkau, maka penulisan menggunakan metode total sampling. yang diambil adalah 55 guru di SMA Muhammadiyah 1 Gresik.

\section{Identifikasi Variabel}

Variabel adalah segala sesuatu yang berbentuk apa saja yang ditetapkan oleh peneliti untuk dipelajari sehingga diperoleh informasi tentang hal tersebut, kemudian ditarik kesimpulan (Sugiyono, 2008:58)

Variabel bebas / Independent

Variabel Independent (bebas) adalah merupakan variabel yang mempengaruhi atau yang menjadi sebab perubahannya atau timbulnya variabel dependen (terikat). Variabel bebas yang digunakan dalam penelitian ini:
a. Budaya Oragnisasi (X1)
b. Lingkungan Kerja (X2)
c. Beban Kerja (X3)
d. Disiplin (X4)

\section{Variabel terikat / Dependent}

Variabel dependent (terikat) adalah suatu variabel yang dipengaruhi atau yang menjadi akibat, karena adanya variabel bebas. Penelitian ini yang menjadi variabel terikat adalah kinerja.

\section{Definisi Operasional Variabel}

Variabel-variabel yang digunakan dalam "Pengaruh budaya organisasi, lingkungan kerja, beban kerja dan disiplin terhadap kinerja guru SMA Muhammadiyah 1 Gresik" adalah:

1. Variabel budaya organisasi $\left(\mathrm{X}_{1}\right)$
a. Inisiatif perseorangan
b. Toleransi terhadap resiko
c. Pengawasan
a. Pola komunikasi

2. Variabel Lingkungan $\operatorname{Kerja}\left(\mathrm{X}_{2}\right)$
a. Penerangan 
b. Kebisingan

c. Ruang gerak yang diperlukan

d. Hubungan karyawan

3. Variabel Beban Kerja (X3)

a. Target Yang Harus Dicapai

b. Kondisi Pekerjaan

c. Standar Pekerjaan

4. Variabel Disiplin Kerja (X4)

a. Disiplin waktu

b. Disiplin peraturan dan tata tertib

c. Disiplin tanggung jawab terhadap penggunaan dan pemeliharaan peralatankantor

5. Kinerja (Y)

a. Ketepatan waktu

b. Deskripsi pekerjaan

c. Kuantitas

d. Kualitas

\section{Pengukuran Variabel}

Untuk memperoleh data kuantitatif variabel diatas diukur dengan menggunakan skala interval dengan memakai metode pengukuran yang dikembangkan oleh Likert. Formasi dan daftar pertanyaan yang diajukan adalah bentuk tertutup, dimana responden hanya diperkenankan untuk

\section{Jenis dan Sumber Data}

Pada penelitian ini, jenis dan sumber data yang dipakai oleh peneliti adalah data primer dan sekunder.

\section{Teknik Pengambilan Data}

Teknik pengambilan data penelitian ini dengan metode angket (kuesioner).

Uji Instrumen

Sebelum digunakan dalam analisis selanjutnya, instrumen dalam penelitian ini terlebih dahulu dilakukan uji validitas dan reliabilitas instrumen tersebut menggunakan SPSS (Social Product of Social Science).

\section{Uji Validitas}

Validitas adalah sejauh mana suatu instrumen mampu mengukur apa yang hendak diukur Sugiyono, (2009:348). Syarat minimum dapat dikatakan valid jika nilai koefisien (r) sama dengan 0,211 atau lebih besar dan dinyatakan tidak valid jika koefisien korelasi kurang dari 0,211 (Sugiyono, 2009). Uji validitas dilakukan dengan mengukur korelasi antara variabel atau item dengan skor total variabel. Cara mengukur validitas konstruk yaitu dengan mencari korelasi antara masing-masing pertanyaan dengan skor total menggunakan rumus teknik korelasi product moment.

\section{Uji Reliabilitas}

Reliabilitas adalah instrumen yang menggambarkan keajegan atau kestabilan alat ukur yang digunakan (Sugiyono, 2009:348). Dengan uji reliabilitas suatu variabel dinyatakan reliabel jika alpha positif, atau $\mathrm{r}_{\text {alpha }}>\mathrm{r}_{\text {tabel }}$.

Rumus: $R=\left[\frac{k}{k-1}\right]\left[1-\frac{\sum \sigma_{b} 2}{\sigma_{b}}\right]$

\section{Uji Asumsi Klasik}

Persamaan regresi yang diperoleh dari analisis data harus menghasilkan estimator linear tidak terbatas atau bersifat BLUE (Best Linear Unbias Estimator) sehingga dalam pengambilan keputusan penentuan hipotesis dalam uji $\mathrm{t}$ dan uji $\mathrm{F}$ tidak terjadi bias. Untuk menghasilkan keputusan yang BLUE maka harus dipenuhi beberapa asumsi yaitu:

1. Autokorelasi

Uji autokorelasi digunakan untuk melihat apakah ada hubungan linear antara error serangkaian observasi yang diurutkan menurut waktu (data time series). Uji autokorelasi perlu dilakukan apabila data yang dianalisis merupakan data time series.

$$
\mathrm{d}=\frac{\sum\left(e_{n}-e_{n-1}\right)^{2}}{\sum e_{x}^{2}}
$$

Uji autokorelasi adalah untuk melihat apakah terjadi korelasi antara suatu periode $\mathrm{t}$ dengan periode sebelumnya $(\mathrm{t}$ 1). Secara sederhana adalah bahwa analisis regresi adalah untuk melihat pengaruh antara variabel bebas terhadap variabel terikat, jadi tidak boleh ada korelasi antara observasi dengan data observasi sebelumnya.

Uji autokorelasi hanya dilakukan pada data time series (runtut waktu) dan tidak perlu dilakukan pada data cross section seperti pada kuesioner di mana pengukuran semua variabel dilakukan secara serempak pada saat yang bersamaan.

2. Multikolinearitas 
Multikolinearitas artinya situasi adanya multikolinearitas di antara variabel independen satu dengan lainnya atau dengan kata lain di antara variabel-variabel independen tersebut dapat dibentuk hubungan antara variabel satu dengan yang lainnya. Uji gejala multikolinearitas digunakan untuk mengetahui ada tidaknya hubungan yang signifikan antara masingmasing variabel bebas yang diteliti. Untuk mengetahui ada tidaknya gejala ini digunakan indikasi nilai VIF (Variance Inflation Factor). Uji gejala multikolinearitas dimaksudkan untuk lebih mengetahui adanya hubungan yang sempurna antara variabel dalam model regresi. Hakim $(2006 ; 301)$ menyebutkan angka toleransi VIF untuk terhindar dari gejala multikolinearitas ini antara 1-5. Usaha untuk mengatasi model regresi yang mengandung multikolinearitas pada penelitian dengan menggunakan data penelitian yang diperoleh dari kuesioner (daftar pertanyaan) dengan cara menambahkan data penelitian Algifari (2009; 85).

\section{Heteroskedastisitas}

Uji heteroskedastisitas bertujuan untuk menguji apakah dalam model regresi terjadi ketidaksamaan varians dan residual satu pengamatan ke pengamatan yang lain. jika varians dari residual satu pengamatan ke pengamatan yang lain tetap, maka disebut homoskedastisitas dan jika berbeda disebut heteroskedastisitas. Model regresi yang baik adalah yang homoskedastisitas atau tidak terjadi heteroskedastisitas.

Uji heteroskedastisitas dilakukan dengan menggunakan uji Glejser, yang dilakukan dengan meregresikan nilai absolut residual yang diperoleh dari model regresi sebagai variabel dependen terhadap semua variabel independen dalam model regresi. Apabila nilai koefisien regresi dari masing-masing variabel bebas dalam model regresi ini tidak signifikan secara statistik, maka dapat disimpulkan tidak terjadi heteroskedastisitas Ghozali (2009 : 271 ).

\section{Teknik Analisis Data}

Analisis kuantitatif digunakan untuk menganalisis data yang bersifat bilangan atau berupa angka-angka. Sumber data yang digunakan dari penelitian ini adalah penarikan data primer dengan menggunakan kuesioner. Data tersebu dikuantitatifkan dengan memberikan skor pada masing-masing jawaban responden Sugiyono (2010:86).

\section{Analisis Regresi Linier Berganda}

Analisis regresi pada dasarnya adalah studi mengenai ketergantungan variabel terikat dengan satu atau lebih variabel bebas dengan tujuan untuk memprediksi nilai rata-rata variabel terikat berdasarkan nilai variabel bebas yang diketahui Gozhali (2009:43).

Persamaan garis regresi linier berganda dapat ditulis sebagai berikut:

$$
\mathrm{Y}=\mathrm{a}+\mathrm{b}_{1} \mathrm{X}_{1}+\mathrm{b}_{2} \mathrm{X}_{2+} \mathrm{b}_{3} \mathrm{X}_{3+} \mathrm{b}_{4} \mathrm{X}_{4+} \mathrm{e}
$$

\section{Uji Hipotesis}

Untuk menguji suatu hipotesis yang dikemukakan oleh peneliti, maka dilakukan uji statistik, yaitu:

\section{Uji t}

Uji ini digunakan untuk menguji pengaruh hipotesis secara parsial :

1. Diduga ada pengaruh secara parsial Budaya Organisasi terhadap kinerja guru SMA Muhammadiyah 1 Gresik.

2. Diduga ada pengaruh secara parsial Lingkungan Kerja terhadap kinerja guru SMA Muhammadiyah 1 Gresik.

3. Diduga ada pengaruh secara parsial Beban Kerja terhadap kinerja guru SMA Muhammadiyah 1 Gresik.

4. Diduga ada pengaruh secara parsial Disiplin terhadap kinerja guru SMA Muhammadiyah 1 Gresik.

5. Diduga adanya pengaruhsecara simultanBudaya Organisasi, Lingkungan Kerja, Beban Kerja dan Disiplin terhadap kinerja guru SMA Muhammadiyah 1 Gresik.

Uji F

Uji ini digunakan untuk menguji pengar ' hipotesis secara simultan, yaitu diduga buda, organisasi, lingkungan kerja, beban kerja dan disiplin mempunyai pengaruh simultan terhadap kinerja guru SMA Muhammadiyah 1 Gresik. 


\section{Gambaran Umum Responden}

Sebagaimana dijelaskan sebelumnya bahwa responden adalah penelitian ini adalah berjumlah 55 guru dan tenaga kependidikan di SMA Muhammadiyah 1 Gresik. Dalam penelitian ini disediakan 60 kuesioner, di mana pengisian kuesioner dengan pendekatan pemberian penjelasan dan panduan kepada responden terdapat 5 kuesioner yang tidak diisi lengkap, sisanya sebanyak 55 kuesioner memenuhi kualifikasi untuk penelitian.

Dari seluruh jumlah kuesioner, diperoleh 55 kuesioner yang digunakan untuk analisis data. Sebelum membahas lebih jauh mengenai hasil penelitian ini, terlebih dahulu akan dibahas mengenai gambaran dari responden yang

Berdasarkan penelitian yang telah dilakukan terhadap 55 guru di SMA Muhammadiyah 1 Gresik, maka jenis kelamin responden ditunjukkan pada tabel berikut:

\section{Tabel.1 Responden Berdasarkan Jenis}

\section{Kelamin}

\begin{tabular}{|c|c|c|}
\hline Jenis Kelamin & Jumlah & $\begin{array}{c}\text { Presentase } \\
(\boldsymbol{\%})\end{array}$ \\
\hline Laki-laki & 30 & 55 \\
\hline Perempuan & 25 & 45 \\
\hline Total & 55 & 100 \\
\hline
\end{tabular}

Berdasarkan penelitian dari kuisoner, maka dapat diketahui karakteristik usia mengenai responden 55 guru di SMA Muhammadiyah 1 Gresik. Responden yang paling muda usianya adalah 22 tahun, sedangkan yang paling tua usianya adalah 55 tahun.

Tabel. 2 Karakteristik Responden Berdasarkan Usia

\begin{tabular}{|c|c|c|}
\hline Umur & Jumlah & $\begin{array}{c}\text { Presentase } \\
(\boldsymbol{\%})\end{array}$ \\
\hline $22-26$ tahun & 4 & 7 \\
\hline $27-31$ tahun & 6 & 10 \\
\hline $32-36$ tahun & 25 & 46 \\
\hline $37-41$ tahun & 10 & 19 \\
\hline $42-46$ tahun & 6 & 10 \\
\hline $47-51$ tahun & 2 & 4 \\
\hline $52-56$ tahun & 2 & 4 \\
\hline Jumlah & 55 & 100 \\
\hline
\end{tabular}

Responden Berdasarkan Pendidikan

Berdasarkan penelitian yang telah dilakukan terhadap 55 guru di SMA Muhammadiyah 1 Gresik, maka pendidikan responden ditunjukkan pada tabel berikut:

\section{Uji Instrumen}

\section{Uji Validitas}

Uji validitas digunakan untuk menguji sejauh mana ketepatan alat pengukur dapat mengungkapkan konsep/gejala yang diukur. Uji Validitas digunakan untuk mengukur sah atau valid tidaknya suatu kuesioner. Suatu kuesioner dikatakan valid jika pertanyaan pada kuesioner mampu untuk mengungkapkan sesuatu yang akan diukur oleh kuesioner tersebut. Cara mengukur validitas dengan melakukan korelasi antar skor butir pertanyaan dengan total skor variabel. Jika rhitung > rtabel dan nilai positif, maka pertanyaan atau indikator dinyatakan valid (Sugiyono, 2008;172).

\section{Uji Reliabilitas}

Uji reliabilitas (kehandalan) adalah nilai yang menunjukan sejauh mana suatu alat pengukut dapat dipercaya dan dapat diandalkan (konsisten). Dalam uji reliabilitas ini suatu butir atau variabel dikatakan reliabel jika $\mathrm{r}_{\text {alpha }}>\mathrm{r}$ table (Santoso, 2009;280).

Hasil pengujian reliabilitas dapat ditunjukkan pada tabel berikut:

Tabel.3 Hasil Uji Reliabilitas

\begin{tabular}{|l|c|c|l|}
\hline Item & alpha & Tabel & Keterangan \\
\hline $\begin{array}{l}\text { Budaya } \\
\text { Organisasi }\end{array}$ & 0,691 & 0,2656 & Reliabel \\
\hline $\begin{array}{l}\text { Lingkungan } \\
\text { Kerja }\end{array}$ & 0,712 & 0,2656 & Reliabel \\
\hline Beban Kerja & 0,708 & 0,2656 & Reliabel \\
\hline Disiplin & 0,784 & 0,2656 & Reliabel \\
\hline $\begin{array}{l}\text { Kinerja } \\
\text { Karyawan }\end{array}$ & 0,705 & 0,2656 & Reliabel \\
\hline
\end{tabular}

Berdasarkan tabel diatas menunjukkan bahwa variabel bebas dan variabel terikat mempunyai nilai $r$ alpha positif dari dan lebih besar dari $r$ tabel, dimana tabel $r$ untuk $\mathrm{df}=\mathrm{N}=$ 55 tingkat signifikansi $5 \%$ adalah 0,2656 . Jadi item - item pertanyaan seluruhnya dianggap reliabel atau handal dalam melakukan fungsinya sebagai alat ukur.

Uji Asumsi Klasik

Uji Autokorelasi

Untuk menguji adanya autokorelasi digunakan uji Durbin Watson batas atas dan batas bawah (du atau dl) bila hasil perhitungan terletak antara selang batas atas dan batas bawah maka 
disimpulkan tidak ada autokorelasi (Ghozali, 2009;95). Dari tabel DW pada taraf signifikan $5 \%$ dengan $\mathrm{n}=55(\mathrm{k}=4)$, maka diperoleh $\mathrm{dl}$ $=1.4136 ; \mathrm{du}=1.7240$ (lihat lampiran Durbin Watson). Dari hasil output persamaan 1 diperoleh $\mathrm{DW}=\mathrm{d}=2.033$.

Tabel 4. Hasil Uji Autokorelasi

Model Summary
\begin{tabular}{|l|c|r|r|r|r|}
\hline Model & R & R Square & $\begin{array}{c}\text { Adjusted } \\
\text { R Square }\end{array}$ & $\begin{array}{c}\text { Std. Error of } \\
\text { the Estimate }\end{array}$ & $\begin{array}{c}\text { Durbin- } \\
\text { Watson }\end{array}$ \\
\hline 1 &, $928^{\mathrm{a}}$ &, 861 &, 850 &, 63497 & 2,033 \\
\hline
\end{tabular}
a. Predictors: (Constant), disiplin, budaya, beban, lingkungan
b. Dependent Variable: kinerja

Karena nilai DW sebesar 2,0 berada pada daerah antara $\mathrm{du}=1,7240$ dan 4-du=2,276, maka menerima Ho bahwa tidak ada autokorelasi.

\section{Uji Multikolinearitas}

Uji Multikolinearitas bertujuan untuk menguji apakah model regresi ditemukan adanya korelasi antar variabel bebas. Dapat dilihat dari Nilai Tolerance dan lawannya, Varian Inflation Factor (VIF). Jika nilai tolerance < 0,10 atau $=$ nilai $\mathrm{VIF}>10$ berarti menunjukkan adanya multikolinearitas (Ghozali, 2009;91).

\section{Hasil Uji Multiklinearitas}

bahwa tidak ada variabel yang memiliki nilai VIF lebih besar dari 10 dan nilai tolerance yang lebih kecil dari $10 \%$, yang berarti bahwa tidak terdapat korelasi antar variabel bebas yang lebih besar dari 95\%. Hal ini berarti bahwa variabel-variabel bebas yang digunakan dalam penelitian tidak menunjukkan adanya gejala multikolinearitas.

\section{Uji Heteroskedastisitas}

Uji heteroskedastisitas bertujuan menguji apakah dalam model regresi terjadi ketidaksamaan variance dari residual satu pengamatan ke pengamatan yang lainnya. Jika variance dari residual satu pengamatan ke pengamatan lain tetap, maka disebut homoskedastisitas. Jika variance tersebut berbeda, maka disebut heteroskedastisitas. Model regresi yang baik adalah yang homoskedastisitas atau tidak terjadi heteroskedastisitas Ghozali $(2011 ; 105)$.

Uji Glejser dilihat dengan cara menghasilkan regresi nilai absolute residual (AbsUi) terhadap variabel independen lainnya. Hasil dari uji
Glejser pada penelitian ini ditunjukkan pada tabel di bawah ini:

Tabel 5. Uji Glejser Hasil Heteroskedastisitas Coefficients (a)

\begin{tabular}{|l|r|c|c|c|c|}
\hline Model & \multicolumn{2}{|c|}{$\begin{array}{c}\text { Unstandardized } \\
\text { Coefficients }\end{array}$} & $\begin{array}{c}\text { Standardized } \\
\text { Coefficients }\end{array}$ & $\mathrm{t}$ & Sig. \\
\hline & \multicolumn{1}{|c|}{$\mathrm{B}$} & $\begin{array}{c}\text { Std. } \\
\text { Error }\end{array}$ & Beta & $\mathrm{B}$ & $\begin{array}{c}\text { Std. } \\
\text { Error }\end{array}$ \\
\hline L Constant) & 1.367 & .692 & & 1.977 & .054 \\
Budaya & -.084 & .032 & -.381 & - & .110 \\
& .072 & .047 & .304 & 1.535 & .131 \\
lingkungan & -.023 & .053 & -.079 & -.428 & .671 \\
Beban & -.030 & .049 & -.128 & -.607 & .547 \\
\hline disiplin & \multicolumn{7}{|l}{}
\end{tabular}

Dari hasil uji Glejser diatas, dapat diketahui bahwa nilai signifikansi ketiga variabel independen lebih dari 0,05. Dengan demikian dapat disimpulkan bahwa tidak terjadi masalah heteroskedastisitas pada model regresi.

\section{Analisis Regresi Linier Berganda}

Analisis ini digunakan untuk mengetahui apakah variabel budaya organisasi, lingkungan kerja, beban kerja dan disiplin berpengaruh terhadap kinerja guru di SMA Muhammadiyah 1 Gresik. Pengujian dilakukan dengan bantuan SPSS didapatkan hasil sebagai berikut:

Analisis ini bertujuan untuk mengetahui pengaruh variabel bebas $(\mathrm{X})$ terhadap variabel terikat (Y) Analisis ini bertujuan untuk mengetahui pengaruh variabel bebas (X) terhadap variabel terikat (Y).

$$
\mathbf{Y}=\mathbf{a}+\mathbf{b}_{1} \mathbf{X}_{1}+\mathbf{b}_{2} \mathbf{X}_{2+} \mathbf{b}_{3} \mathbf{X}_{3+} \mathbf{b}_{4} \mathbf{X}_{4+} \mathbf{e}
$$

Koefisien Determinasi ( $\mathbf{R}^{2}$ ) dan Koefisien Korelasi Ganda

\section{Tabel 6. Model Summary}

Model Summary

\begin{tabular}{|c|c|c|c|c|}
\hline Model & $\mathrm{R}$ & R Square & $\begin{array}{l}\text { Adjusted } \\
\text { R Square }\end{array}$ & $\begin{array}{l}\text { Std. Error of } \\
\text { the Estimate }\end{array}$ \\
\hline 1 &, $928^{\mathrm{a}}$ & 861 & 850 &, 63497 \\
\hline
\end{tabular}

1. Adjusted R square sebesar 0,850 dapat dikatakan bahwa nilai kinerja guru (Y) sebesar $85 \%$ disebabkan oleh variabel budaya organisasi (X1), lingkungan kerja 
(X2), beban kerja (X3), disiplin (X4), sedangkan sisanya $15 \%$ disebabkan oleh faktor lain yang tidak ada dalam model ini.

2. $\mathrm{R}$ square sebesar 0,861 dapat dikatakan bahwa variabel budaya organisasi (X1), lingkungan kerja (X2), beban kerja (X3), disiplin (X4) mampu menjelaskan nilai kinerja guru (Y) sebesar $86,1 \%$ sedangkan sisanya $13,9 \%$ disebabkan oleh faktor lain yang tidak ada dalam model ini.

1. $\mathrm{R}^{2}$ sebesar 0,928 dapat dikatakan bahwa variabel budaya organisasi (X1), lingkungan kerja (X2), beban kerja (X3), disiplin (X4) mampu menjelaskan nilai kinerja guru (Y) sebesar 92,8\% sedangkan sisanya $7,2 \%$ disebabkan oleh faktor lain yang tidak ada dalam model ini.

\section{Uji Hipotesis}

Uji t

Uji hipotesis dilakukan untuk mengetahui apakah variabel eksogen berpengaruh terhadap variabel endogen yang digunakan dalam penelitian. Uji hipotesis yang digunakan adalah uji t. Uji t digunakan untuk melihat pengaruh parsial (masing-masing) variabel eksogen terhadap variabel endogen. Tingkat kepercayaan atau tingkat signifikansi yaitu $\propto=5 \% \div 2=$ $2,5 \%$. Perumusan hipotesisnya adalah sebagai berikut:

Jika $t_{\text {hitung }}>t_{\text {tabel, }}$ maka Ho ditolak dan $\mathrm{Ha}$ diterima

Jika $\mathrm{t}_{\text {hitung }}<\mathrm{t}_{\text {tabel }}$, maka Ho diterima dan Ha ditolak

\section{Hasil Uji t}

Berdasarkan hasil perhitungan, nilai $t_{\text {hitung }}$ sebesar 4,542 nilai $t_{\text {tabel }}$ sebesar 2,008, maka Ho ditolak dan Ha diterima. Dapat disimpulkan, bahwa budaya organisasi berpengaruh terhadap kinerja karyawan.

parsial antara lingkungan kerja terhadap kinerja karyawan, peneliti menggunakan tahap berupa penetapan hipotesis, pengolahan data kuantitatif dengan SPSS, dan membandingkan nilai $t$ hitung dengan $t$ tabel. Adapun hipotesis yang ditetapkan yaitu:

$\mathrm{Ha}=$ lingkungan kerja berpengaruh terhadap kinerja guru di SMA Muhammadiyah 1 Gresik.

Ho = lingkungan kerja tidak berpengaruh terhadap kinerja guru di SMA Muhammadiyah 1 Gresik.
Pengolahan data dengan menggunakan SPSS, diperoleh nilai t hitung sebesar -437 dan nilai $\mathrm{t}$ tabel dengan taraf signifikansi 5\% (dua sisi) sebesar 2,008. Selanjutnya nilai $\mathrm{t}$ hitung dan $\mathrm{t}$ tabel dibandingkan, dengan ketentuan:

Jika $t_{\text {hitung }}>t_{\text {tabel }}$, maka Ho ditolak dan $\mathrm{Ha}$ diterima

Jika $\mathrm{t}_{\text {hitung }}<\mathrm{t}_{\text {tabe }} \mathrm{l}$, maka Ho diterima dan $\mathrm{Ha}$ ditolak

Berdasarkan hasil perhitungan, nilai $t_{\text {hitung }}$ sebesar -0,437 nilai $\mathrm{t}_{\text {tabel }}$ sebesar 2,008, maka Ho diterima dan Ha ditolak. Dapat disimpulkan, bahwa lingkungan tidak berpengaruh terhadap kinerja karyawan.

\section{Pengaruh variabel Beban Kerja (X3) terhadap Kinerja Karyawan (Y)}

Untuk melihat pengaruh parsial antara beban kerja terhadap kinerja karyawan, peneliti menggunakan tahap berupa penetapan hipotesis, pengolahan data kuantitatif dengan SPSS, dan membandingkan nilai $\mathrm{t}$ hitung dengan $\mathrm{t}$ tabel. Adapun hipotesis yang ditetapkan yaitu:

$\mathrm{Ha}=$ beban kerja berpengaruh terhadap kinerja guru di SMA Muhammadiyah 1 Gresik.

Ho = beban kerja tidak berpengaruh terhadap kinerja guru di SMA Muhammadiyah 1 Gresik. Pengolahan data dengan menggunakan SPSS, diperoleh nilai t hitung sebesar 2,640 dan nilai $t$ tabel dengan taraf signifikansi 5\% (dua sisi) sebesar 2,008. Selanjutnya nilai $\mathrm{t}$ hitung dan $\mathrm{t}$ tabel dibandingkan, dengan ketentuan:

Jika $t_{\text {hitung }}>\mathrm{t}_{\text {tabel }}$, maka Ho ditolak dan $\mathrm{Ha}$ diterima

Jika $\mathrm{t}_{\text {hitung }}<\mathrm{t}_{\text {tabe }} \mathrm{l}$, maka Ho diterima dan Ha ditolak

Berdasarkan hasil perhitungan, nilai $t_{\text {hitung }}$ sebesar 2,640 nilai $t_{\text {tabel }}$ sebesar 2,008, maka Ho ditolak dan Ha diterima. Dapat disimpulkan, bahwa beban kerja berpengaruh terhadap kinerja karyawan.

\section{Pengaruh variabel disiplin (X4) terhadap} Kinerja Karyawan (Y)

Untuk melihat pengaruh parsial antara disiplin terhadap kinerja karyawan, peneliti 
menggunakan tahap berupa penetapan hipotesis, pengolahan data kuantitatif dengan SPSS, dan membandingkan nilai $\mathrm{t}$ hitung dengan $\mathrm{t}$ tabel. Adapun hipotesis yang ditetapkan yaitu:

$\mathrm{Ha}=$ disiplin berpengaruh terhadap kinerja guru di SMA Muhammadiyah 1 Gresik.

Ho = disiplin tidak berpengaruh terhadap kinerja guru di SMA Muhammadiyah 1 Gresik. Pengolahan data dengan menggunakan SPSS, diperoleh nilai t hitung sebesar 7,412 dan nilai $t$ tabel dengan taraf signifikansi 5\% (dua sisi) sebesar 2,008. Selanjutnya nilai $t$ hitung dan $t$ tabel dibandingkan, dengan ketentuan:

Jika $t_{\text {hitung }}>t_{\text {tabel }}$, maka Ho ditolak dan $\mathrm{Ha}$ diterima

Jika $t_{\text {hitung }}<\mathrm{t}_{\text {tabe }} \mathrm{l}$, maka Ho diterima dan Ha ditolak

Berdasarkan hasil perhitungan, nilai $t_{\text {hitung }}$ sebesar 7,412 nilai $t_{\text {tabel }}$ sebesar 2,008, maka Ho ditolak dan Ha diterima. Dapat disimpulkan, bahwa disiplin berpengaruh terhadap kinerja karyawan.

\section{Tabel 7. Uji Secara Simultan (Uji F)}

\begin{tabular}{|c|c|c|c|c|c|c|}
\hline \multicolumn{7}{|c|}{ ANOVA } \\
\hline Model & & $\begin{array}{l}\text { Sum of } \\
\text { Squares }\end{array}$ & df & Mean Square & $\mathrm{F}$ & Sig. \\
\hline & Regression & 125,186 & 4 & 31,296 & 77,622 &, $000^{2}$ \\
\hline & Residual & 20,160 & 50 & , 403 & & \\
\hline & Total & 145,345 & 54 & & & \\
\hline
\end{tabular}

a. Predictors: (Constant), disiplin, budaya, beban, lingkungan

b. Dependent Variable: kinerja

Berdasarkan tabel diatas disimpulkan bahwa Ho ditolak dan Ha diterima, hal ini karena $\mathrm{F}$ hitung $77,622>\mathrm{F}$ tabel 2.557 dan nilai signifikan $\mathrm{F}$ yang lebih kecil dari $0,05(0,000<0,05)$. Dengan demikian dapat dikatakan bahwa budaya organisasi (X1), lingkungan kerja (X2), beban kerja(X3), disiplin (X4) secara simultan berpengaruh kinerja karyawan (Y).

\section{Interpretasi Hasil}

Berdasarkan penelitian dan analisis yang peneliti lakukan dengan menggunakan aplikasi SPSS, maka peneliti dapat menginterpretasikan hasil sebagai berikut:

\section{Budaya Organisasi Berpengaruh Terhadap Kinerja Karyawan}

Hasil penelitian menunjukkan bahwa nilai $t$ hitung/t penelitian sebesar $4,542>$ nilai $t$ tabel sebesar 2,008, sehingga Ho ditolak dan Ha diterima, atau budaya organisasi terbukti berpengaruh secara signifikan terhadap kinerja guru SMA Muhammadiyah 1 Gresik.

Sesuai pendapat Robbins (2009:56) mendefinisikan budaya organisasi (organization culture) sebagai suatu sistem makna bersama yang dianut oleh anggotaanggota yang membedakan organisasi dengan organisasi lain. Lebih lanjut, Robbins (2002:279) menyatakan bahwa sistem pemaknaan bersama dibentuk oleh warganya yang sekaligus menjadi pembeda dengan organisasi lain.

2. Lingkungan Kerja Tidak Berpengaruh Terhadap Kinerja Karyawan

Hasil penelitian menunjukkan bahwa nilai $\mathrm{t}$ hitung/t penelitian sebesar $-0,437<$ nilai $\mathrm{t}$ tabel sebesar 2,008, sehingga Ho diterima dan $\mathrm{Ha}$ ditolak, atau lingkungan kerja terbukti tidak berpengaruh terhadap kinerja guru SMA Muhammadiyah 1 Gresik.

Lingkungan Kerja tidak berpengaruh terhadap kinerja guru dikarenakan meskipun lingkungan kerja diperbaiki atau diperbagus tidak akan mempengaruhi kinerja guru karena guru mempunyai sasaran kerja pegawai yang harus ditaati oleh setiap guru.

3. Beban Kerja Berpengaruh Terhadap Kinerja Karyawan

Hasil penelitian menunjukkan bahwa nilai $\mathrm{t}$ hitung/t penelitian sebesar 2,640> nilai $\mathrm{t}$ tabel sebesar 2,008, sehingga Ho ditolak dan Ha diterima, atau beban kerja terbukti berpengaruh secara signifikan terhadap kinerja guru SMA Muhammadiyah 1 Gresik. Sesuai pendapat Irwandy yangmenyatakan beban kerja adalah frekuensi kegiatan ratarata dari masing-masing pekerjaan dalam jangka waktu tertentu. Beban kerja meliputi beban kerja fisik maupun mental. Akibat beban kerja yang terlalu berat atau kemampuan fisik yang terlalu lemah dapat mengakibatkan seorang pegawai menderita gangguan atau penyakit akibat kerja (Irwandy, 2007)

\section{Disiplin Berpengaruh Terhadap Kinerja} Karyawan

Hasil penelitian menunjukkan bahwa nilai $\mathrm{t}$ hitung/t penelitian sebesar 7,412> nilai t tabel sebesar 2,008, sehingga Ho ditolak dan $\mathrm{Ha}$ diterima, atau disiplin terbukti 
berpengaruh secara signifikan terhadap kinerja guru SMA Muhammadiyah 1 Gresik.

Sesuai dengan pendapat Siagian (2009: 305) Disiplin merupakan tindakan manajemen untuk mendorong para anggota organisasi memenuhi tuntutan berbagai ketentuan tersebut. Dengan adanya definisi diatas dapat disimpulkan, disiplin pada hakekatnya merupakan pembatasan kebebasan dari pegawai. Disiplin dalam suatu perusahaan dapat ditegakkan apabila sebagian besar peraturan-peraturannya ditaati oleh sebagaian besar para pegawai atau pegawainya, dalam prakteknya untuk mengusahakan seluruh peraturan ditaati oleh setiap pegawai. Oleh kar ena itu dalam praktek bila suatu perusahaan telah dapat mengusahakan sebagian besar peraturan-peraturan ditaati oleh sebagian besar pegawainya maka sebenarnya disiplin sudah dapat ditegakkan.

\section{Pengaruh Budaya Organisasi,} Lingkungan Kerja, Beban Kerja dan Disiplin Secara Simultan Terhadap Kinerja Karyawan

Hasil uji hipotesis secara simultan melalui uji $\mathrm{F}$, nilai $\mathrm{F}$ hitung $15,575>\mathrm{F}$ tabel 2,525 pada taraf signifikan $5 \%$, menyatakan bahwa variabel Budaya Orgaisasi, Lingkungan Kerja, Beban Kerja dan Disiplin secara simultan terbukti berpengaruh secara signifikan terhadap kinerja guru SMA Muhammadiyah 1 Gresik.

Sesuai dengan pendapat Siagian (2002:124) bahwa kinerja dipengaruhi oleh beberapa faktor yaitu kompensasi, lingkungan kerja, budaya oraganisasi, kepemimpinan, motivasi, disiplin kerja, kepuasan kerja, beban kerja, komunikasi dan faktor-faktor lainnya.

\section{SIMPULAN \\ Kesimpulan}

Setelah dilakukan pengujian keseluruhan hipotesis yang diajukan dalam penelitian ini, maka kesimpulannya sebagai berikut:

1. Budaya Organisasi berpengaruh secara signifikan terhadap Kinerja Guru di SMA Muhammadiyah 1 Gresik.

2. Lingkungan Kerja tidak berpengaruh secara signifikan terhadap Kinerja Guru di
SMA Muhammadiyah 1 Gresik.

3. Beban Kerja berpengaruh secara signifikan terhadap Kinerja Guru di SMA Muhammadiyah 1 Gresik.

4. Disiplin berpengaruh secara signifikan terhadap Kinerja Guru di SMA Muhammadiyah 1 Gresik.

5. Budaya Organisasi, Lingkungan Kerja, Beban Kerja, Disiplin berpengaruh secara simultan terhadap Kinerja Guru (Y) di SMA Muhammadiyah 1 Gresik.

\section{Rekomendasi}

Berdasarkan pada hasil penelitian dan hasil perhitungan yang diperoleh maka dapat disimpulkan :

1. Bagi SMA Muhammadiyah 1 Gresik Mengingat hasil $t_{\text {hitung }}$ Disiplin lebih tinggi dari pada Budaya Organisasi, Lingkungan Kerja, dan Beban Kerja, maka pihak kepala sekolah harus lebih meningkatkan disiplin waktu, disiplin terhadap peraturan, tata tertib serta disiplin terhadap penggunaan dan pemeliharaan peralatan kantor terhadap guru guna meningkatkan kinerja guru SMA Muhammadiyah 1 Gresik.

2. Bagi Peneliti Selanjutnya

Diharapkan hasil penelitian ini dapat digunakan untuk referensi atau pendukung bagi penelitian selanjutnya yang akan mengambil tema yang sama, peneliti merekomendasikan untuk menambah variabel lain yang dapat mempengaruhi kinerja dan menggunakan pendekatan dan analisis yang berbeda untuk mengetahui perbedaan analisis satu dengan analisis yang lainnya.

\section{DAFTAR PUSTAKA}

Algifari. 2009. Analisis Statistik untuk Bisnis dengan Regresi, Korelasi, dan Nonparametrik. Edisi Pertama. Yogyakarta: BPFE.

Ardana, I Komang., Mujiati, Ni Wayan., Utama, I Mudiartha. 2012. Manajemen Sumber Daya Manusia. Yogyakarta: Graha Ilmu.

Dani Praditya Setiawan. 2016. "Pengaruh Beban Kerja Dan Lingkungan Kerja Terhadap Kinerja Kerja Karyawan PT. Macanan Jaya Cemerlang Klaten" Prodi Manajemen Fakultas Ekonomi Universitas Negeri Yogyakarta. 
Davis,Keith.2006 .Perilaku dalam Organisasi,Edisi7 bahasa Indonesia, Jilid 1.Jakarta:Penerbit Erlangga

Eni, Rernawan. 2011. Organization Culture, Budaya Organisasi dalam persektif Ekonomi dan Bisnis. Bandung : Alfabeta.

Fikratunil Khasifah. 2015. "Pengaruh Disiplin Kerja, Beban Kerja Dan Lingkungan Kerja Terhadap Kinerja Pegawai (Studi pada Balai Besar Wilayah Sungai Pemali- Juana Semarang)" Fakultas Ekonomika Dan Bisnis Universitas Diponegoro Semarang.

Ghozali, Imam, 2009. Aplikasi Analisis Multivariate Dengan Program SPSS, Edisi Keempat, Penerbit Universitas Diponegoro.

Harmusa Oktaviani $2014 \quad$ "Pengaruh Lingkungan Kerja Dan Budaya Organisasi Terhadap Kinerja Karyawan Pada Koperasi Sumber Rejeki Rembang Jawa Tengah" Fakultas Ekonomika Dan Bisnis Universitas Diponegoro Semarang.

Hakim, Abdul. 2006. Analisis Pengaruh Motivasi, Komitmen Organisasi Dan Iklim Organisasi Terhadap Kinerja Pegawai Pada Dinas Perhubungan Dan Telekomunikasi Provinsi Jawa Tengah. JRBI. Vol 2.No 2. Hal: 165180.

Hariyati, M. 2011. Pengaruh Beban Kerja Terhadap Kelelahan Kerja Pada Pekerja Linting Manual di PT Djitoe Indonesia Tobacco Surakarta. [Skripsi Ilmiah]. Surakarta: Fakultas Kedokteran UNS.

Handoko, T dan Hani. 2008. Manajemen. Cetakan Kedelapan belas. BPFE Yogyakarta, Yogyakarta.

Hasibuan, Malayu S. P.2008. Manajemen Sumber Daya Manusia, Jakarta : PT.Bumi Aksara. 2010. Manajemen Sumber Daya Manusia. Jakarta: PT. Bumi Aksara.

Irwandy, 2007. Faktor-Faktor Yang

Berhubungan Dengan Beban Kerja di

Unit Rawat Inap RS Jiwa Makassar

Tahun 2006. Makasar.

Kharisma, Gogy Bara 2013 "Pengaruh Budaya Organisasi dan Lingkungan Kerja Terhadap Kinerja Karyawan Koperasi Serba Usaha Setya Usaha di kabupaten
Jepara ".Jurusan Manajemen Fakultas

Ekonomi Universitas Negeri Semarang.

Kunandar. 2007. Guru Profesional :

Implementasi Kurikulum Tingkat Satuan

Pendidikan (KTSP) dan Sukses dalam

Sertifikasi Guru. Jakarta :Raja grafindo Persada 